\title{
Pronounced hypoxia in the subventricular zone following traumatic brain injury and the neural stem/progenitor cell response
}

\author{
Gisela Baumann ${ }^{1}$, Lissette Travieso ${ }^{1}$, Daniel $\mathrm{J} \mathrm{Liebl}^{1}$ and Michelle $\mathrm{H}$ Theus ${ }^{2}$ \\ ${ }^{1}$ The Miami Project to Cure Paralysis and Department of Neurological Surgery, University of Miami, Miami, FL 33136, USA; ${ }^{2}$ The \\ Department of Biomedical Sciences and Pathobiology, Virginia-Maryland Regional College of Veterinary Medicine, Blacksburg, VA \\ 24061, USA \\ Corresponding author: Michelle H Theus. Email: mtheus@vt.edu
}

\begin{abstract}
Traumatic brain injury (TBI) elicits identifiable changes within the adult subventricular zone (SVZ). Previously, we demonstrated that EphB3/ephrinB3 interaction inhibits neural stem/progenitor cell (NSPC) proliferation and downregulating this pathway following TBI plays a pivotal role in the expansion of the SVZ neurogenic compartment. It remains unclear, however, what early initiating factors may precede these changes. Using hypoxyprobe-1 $(\mathrm{HPb})$ to identify regions of low oxygen tension or hypoxia $(<1 \%)$, we found $\mathrm{HPb}$ uptake throughout the cortex (CTX), corpus callosum (CC) and SVZ within the first $24 \mathrm{~h}$ following controlled cortical impact (CCl) injury. At this early time point, HPb co-localized with EphB3 in the SVZ. NSPC specific markers also colocalized with $\mathrm{HPb}$ staining throughout the lateral wall of the ventricle. To determine the cell autonomous effects of hypoxia on EphB3/ephrinB3 signaling in NSPCs, we used an in vitro model of hypoxia to mimic 1\% oxygen in the presence and absence of soluble aggregated ephrinB3 (eB3). As expected, hypoxia stimulated the uptake of 5-bromo-2'-deoxyuridine (BrdU) and reduced cell death. Coincident with these proliferative changes, both Hif1- $\alpha$ and phospho (p)-AKT were increased while EphB3 expression was decreased. Stimulation of EphB3 attenuated hypoxia-induced proliferation and prevented phosphorylation of AKT. Hif1- $\alpha$ accumulation, on the other hand, was not affected by EphB3/ephrinB3 signaling. These findings indicate that this pathway limits the NSPC response to hypoxic stimuli. These studies also suggest that early transient changes in oxygen tension following localized cortical injury may initiate a growth-promoting response in the SVZ.
\end{abstract}

Keywords: Hypoxia, Eph, ephrin, subventricular zone, AKT, Hif1- $\alpha$, neural stem/progenitor cell, traumatic brain injury

Experimental Biology and Medicine 2013; 238: 830-841. DOI: 10.1177/1535370213494558

\section{Introduction}

Traumatic brain injury (TBI) is a progressive, potentially debilitating neurological condition initiated by mechanical forces, followed by a well-described cascade of secondary events including hypoxia, ischemia, excitotoxicity and free radical damage. In contrast, there is a stimulatory or growth-promoting effect on the neural stem/progenitor cell (NSPC) compartment in the subventricular zone (SVZ). The SVZ is the largest neurogenic region in the adult mammalian brain, lines the lateral ventricles (LV), and extends into the rostral migratory stream (RMS), where migrating neuroblasts navigate rostral through a ribbon of astrocytes to the olfactory bulb. ${ }^{1-6}$ Shortly after TBI, the proliferative rate of NSPCs within the ipsilateral SVZ is greatly enhanced, and over the first few weeks, migrating neuroblasts are observed exiting the RMS. ${ }^{7-11}$
Interestingly, enhanced proliferation in the contralateral SVZ is also observed but to a lesser extent. ${ }^{8,9,12}$ Whether these expansion and migratory changes are instituted to help counterbalance TBI-induced neuronal loss in an effort to maintain or restore function through trophic support or cellular replacement is under intense investigation.

Several factors have been implicated in regulating proliferation and migration ${ }^{2,13-17}$ in the SVZ, and among those are ephrins and erythropoietin-producing hepatocellular (Eph) family of receptor tyrosine kinases. Ephrins are membranebound ligands and tethered to the cell surface, by either a glycosylphosphatidylinositol (GPI)-anchor (A-class) or transmembrane domain (B-class). Eph receptors, which belong to the largest family of receptor tyrosine kinases, are also subdivided into two A- and B-class, based on their preferential binding for one particular ephrin 
subgroup. Therefore, receptor activation by ligand binding is a direct result of cell-cell contact, and interactions between ephrins and Eph receptors can result in bidirectional signaling from both the ligand and receptor. ${ }^{18}$ Although the binding between ligands and receptors is considered very promiscuous, specific ligand-receptor interactions exist within each subclass. ${ }^{19}$ Using a gene-targeted approach, we previously demonstrated that EphB3 forward signaling acts as a suppressive cue to limit NSPC proliferation and survival in the SVZ. Stimulation of this pathway using soluble recombinant ephrinB3-Fc chimeric molecules into the LVs attenuated TBI-induced proliferation in the neurogenic compartment. ${ }^{7}$ Additional factors such as basic fibroblast growth factor (bFGF), brain-derived neurotrophic factor (BDNF), vascular endothelial growth factor (VEGF), transforming growth factor (TGF), sonic hedgehog (shh), and bone morphogenic proteins (BMPs) have also been shown to stimulate neurogenesis after brain injury. ${ }^{20}$ Upregulation of multiple growth-promoting signaling pathways could be converging on the neurogenic compartment to stimulate neurogenesis. However, it is unclear whether these soluble molecules actually originate from the SVZ or are blood-borne factors that circulate through the SVZ vascular network after injury. ${ }^{21}$ Additionally, activated astrocytes and microglial are both known to secrete a variety of growth factors that could create a gradient of trophic support that may affect neural progenitor cell activities. $^{22,23}$

Although the orchestration of trophic signals leading to TBI-induced changes in the SVZ remains obscure, alterations in oxygen $\left(\mathrm{O}_{2}\right)$ tension or hypoxia could be an early stimulating event. Hypoxic cell culture conditions $\left(<5 \% \mathrm{O}_{2}\right)$ have demonstrated a strong correlation between low $\mathrm{O}_{2}$ availability and the beneficial effects on stem cell functions such as enhanced proliferation, survival and differentiation. Although it has been shown that a majority of the dividing stem cell occupants of the SVZ are perivascular, others may possibly occupy hypoxic sub-compartments and be regulated by $\mathrm{O}_{2}$ gradients. More intriguing is whether lowered $\mathrm{O}_{2}$ tension created by brain trauma extends into the neurogenic compartments in the adult brain. As a starting point for testing these ideas, we screened for areas of low $\mathrm{O}_{2}$ partial pressure $\left(\sim 1.3 \% \quad \mathrm{O}_{2}\right.$ or $\left.<10 \mathrm{mmHg}\right)$ using Hypoxyprobe-1 $(\mathrm{HPb})$ immunostaining in both shaminjured and TBI-injured mice. Our previous findings demonstrate that EphB3/ephrinB3 interactions negatively regulate NSPCs in the SVZ. Here, we further examined the cell autonomous effects of hypoxia on EphB3 signaling in cultured NSPCs.

\section{Results}

\section{Pronounced hypoxia in the SVZ after TBI}

Cerebral hypoxia develops as part of the secondary injury following primary mechanical trauma to the brain. To visualize the presence of low oxygen in the injured tissue following a controlled cortical impact (CCI) model of TBI, animals were injected with $100 \mathrm{mg} / \mathrm{kg}$ of $\mathrm{HPb}$ (pimonidazole hydrochloride) or PBS (vehicle control) at the time of impact $(0 \mathrm{~h}), 1.5 \mathrm{~h}$ and $24 \mathrm{~h}$ after $\mathrm{CCI}$ injury. $\mathrm{HPb}$ binds only to cells that have oxygen concentrations less than $\mathrm{pO}_{2}$ of $10 \mathrm{mmHg}(<1 \%)$, where protein adducts of reductively activated $\mathrm{HPb}$ are formed and then analyzed using rabbit anti$\mathrm{HPb}$ and $\mathrm{DAB}$ staining on perfuse-fixed sagittal tissue sections. As expected, we observed the presence of $\mathrm{HPb}$ at the site of injury in the cortex (CTX) and underlying corpus callosum (CC) of CCI-injured mice (Figure 1c to f; brown staining). No staining was seen in $\mathrm{HPb}$-injected shaminjured (Figure 1a) or PBS-injected CCI-injured mice (Figure $1 \mathrm{~b}$ ). The greatest intensity of staining was seen at $1.5 \mathrm{~h}$ after impact. It was also the only time in which the hippocampus and dentate gyrus appear to be transiently $\mathrm{HPb}$-positive (Figure 1d). Importantly, the area lining the $\mathrm{LV}$, both dorsal and ventral subregions of the SVZ, was positive for $\mathrm{HPb}$ staining at all-time points but most notable at $24 \mathrm{~h}$ (Figure 1f; black arrows) suggesting that the NSPCs residing in the lateral wall of the ventricle may be influenced by the low oxygen environment.

To determine which cells in the SVZ may be HPb-positive, we used double immunofluorescence and confocal image analysis on sagittal sections. At low magnification, we observed $\mathrm{HPb}$ expression (red) throughout the CTX, lateral wall of the ventricle and in the RMS (Figure $2 \mathrm{~b}$ and d) at $1.5 \mathrm{~h}$ post-injury compared to sham-injured mice (Figure 2a). In addition to the expected $\mathrm{HPb}$ expression on injured NISSL-positive neurons in the CTX (Figure 2e and $\mathrm{f}$ ), we observed sustained $\mathrm{HPb}$ expression in the dorsal wall of the ventricle (Figure 2i and j) which extended ventral (data not shown) at $24 \mathrm{~h}$ post-TBI compared to sham-injured control (Figure $2 \mathrm{~g}$ and $\mathrm{h}$ ). HPb co-labeled with neuroblasts marker doublecortin (DCX; Figure 2k) and NSPC markers MASH1 (Figure 2l) and glial fibrillary acidic protein (GFAP; Figure $2 \mathrm{~m}$ ). These data indicate that $\mathrm{HPb}$ expression is present on multiple NSPC types in the SVZ following TBI.

\section{EphB3 expression in the hypoxic SVZ after TBI}

Our previous findings indicate that EphB3 receptor is expressed on NSPCs in the SVZ and limits their proliferation while in the presence of ephrinB3 ligand. ${ }^{24,25}$ In order to evaluate the effects of hypoxia on EphB3/ephrinB3 signaling, we first analyzed their regional expression in the SVZ and surrounding areas after TBI. Initially, we took advantage of a transgenic knock-in mouse where $\beta$-galactosidase (ephrinB3 ${ }^{\beta g a l}$ ) replaces the cytoplasmic domain to visualize ephrinB3 expression. We observed X-gal staining throughout the brain, including the striatum (St), septum, and CC (Figure 3c); however, we did not observe ephrinB3 within the SVZ (Figure 3c1). Co-labeling GFAP-positive NSPCs (green) and PSA-NCAM-expressing neuroblasts (red) on ephrinB3 ${ }^{\text {Bgal }}$ tissue sections show NSPCs residing in the SVZ exist along a border of ephrinB3 expression in the adjacent tissue (Figure 3a1 to c1). Neural progenitor cells in the SVZ, therefore, come in contact with and are regulated by neighboring ephrinB3. EphB3, on the other hand, is expressed in the SVZ, as previously described, ${ }^{24}$ and shown here to co-label with $\mathrm{HPb}$ at $24 \mathrm{~h}$ after TBI (Figure $3 \mathrm{~d}$ to $\mathrm{g}$ ).

Next, we examined the cell autonomous effects of hypoxia on EphB3 signaling by culturing NSPCs at $1 \%$ oxygen 

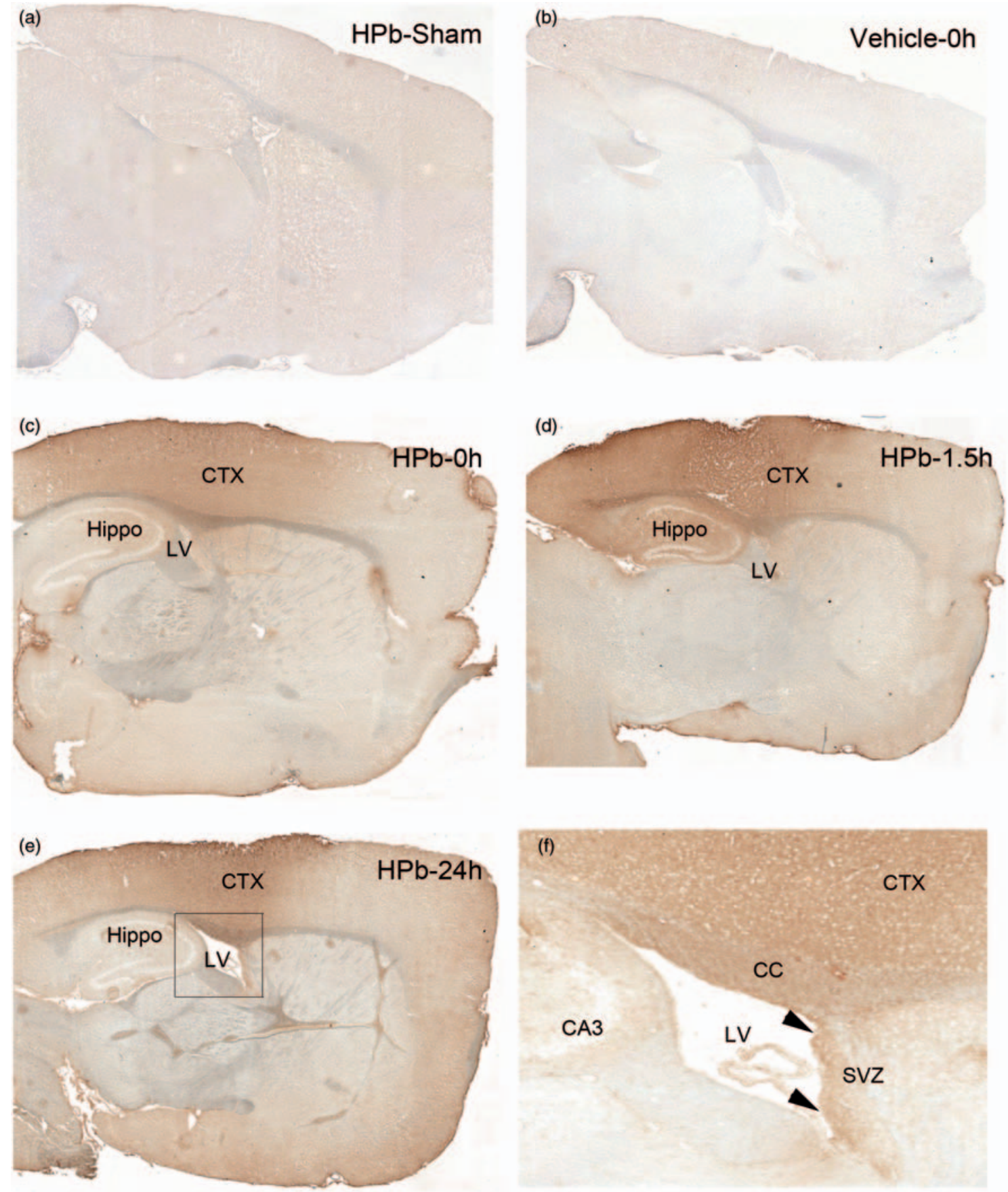

Figure $1 \mathrm{HPb}$ expression in the adult murine brain after $\mathrm{CCl}$ injury. Uptake of hypoxyprobe ( $\mathrm{HPb}$ ) by low oxygen-bearing cells was visualized using immunohistochemistry and DAB staining on sagittal brain sections. Compared to sham-injured (a) or CCl-injured vehicle injected control (b), induction of $\mathrm{HPb}$ expression was seen at $0 \mathrm{~h} \mathrm{(c),} 1.5 \mathrm{~h}(\mathrm{~d})$, and $24 \mathrm{~h}$ (e) after CCl injury. DAB staining (brown) shows HPb expression is localized to the impacted cortex, corpus callosum, and the lateral wall of the lateral ventricle. $\mathrm{HPb}$ expression was also seen in the hippocampus but only at $1.5 \mathrm{~h}$ post-injury. At higher magnification, we observed that $\mathrm{HPb}$ remained expressed in the SVZ at $24 \mathrm{~h}$ (f; inset from e; black arrows) post-CCI injury. CTX: cortex; CC: corpus callosum; LV: lateral ventricle; Hippo: hippocampus. (A color version of this figure is available in the online journal)

in the presence or absence of ephrinB3. Using a monolayer of NSPCs derived from the SVZ, we confirmed the expression of EphB3 and other known ephrin-B ligands and Eph receptors whose expression are also implicated in regulating activities in the adult SVZ. ${ }^{24,26-28}$ Using RT-PCR, we confirmed that EphB3 is expressed on NSPCs, while ephrinB3 is absent. As expected, we also observed the presence of ephrinB1 and ephrinB2 (Figure 4d) and their cognate receptors EphB1 and EphB2 as well as EphA4, which has been shown to bind ephrinB3 with high affinity. In addition to the presence of EphB3 and EphA4 transcripts, we show their cellular localization on NSPCs by immunofluorescence (Figure $4 \mathrm{a}$ and b) but not ephrinB3 ligand (Figure 4c). 

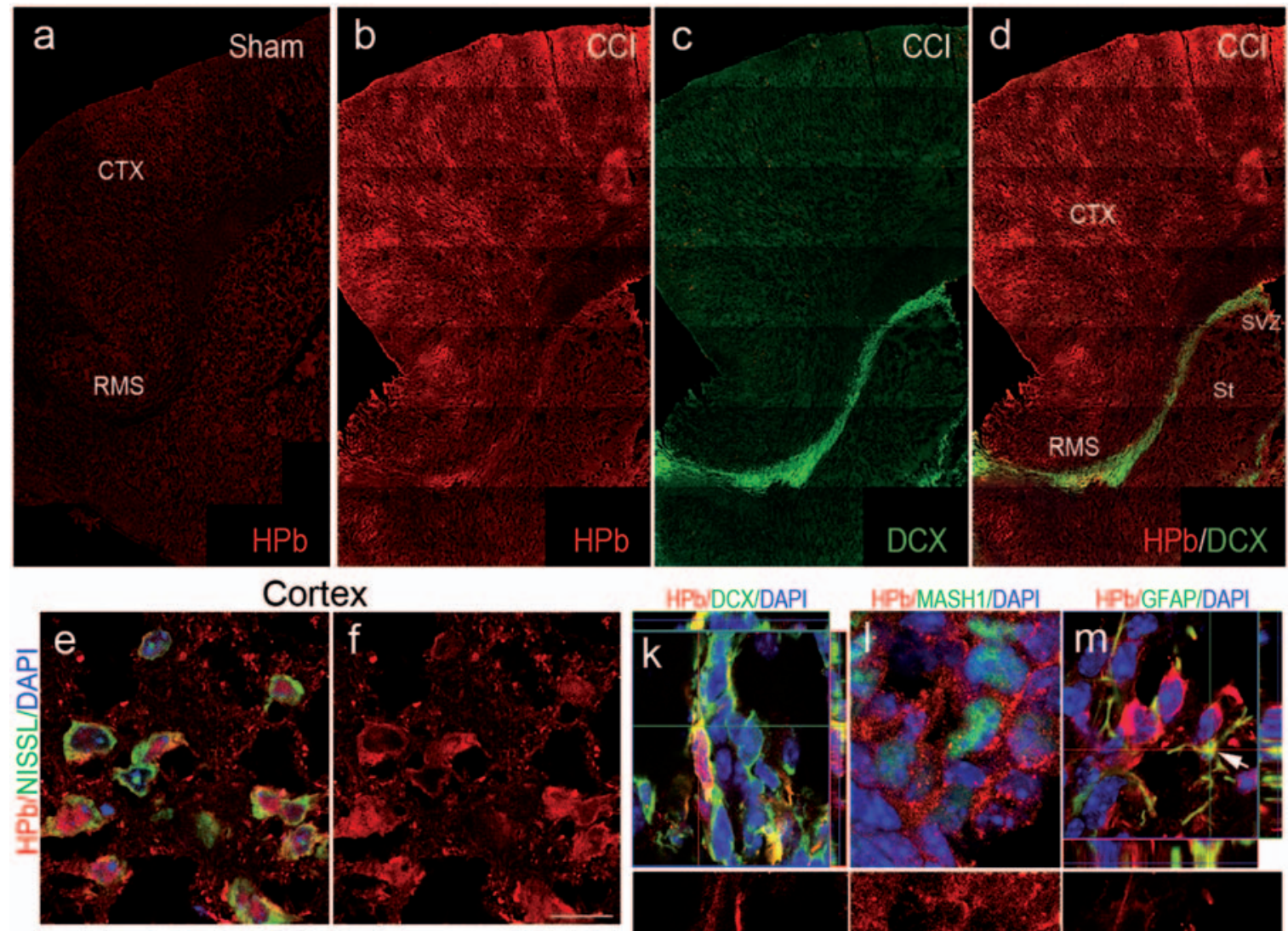

HPSIDCXIDAPI

HPBMASH1/DAP|

IPBIGFAP/DAPI

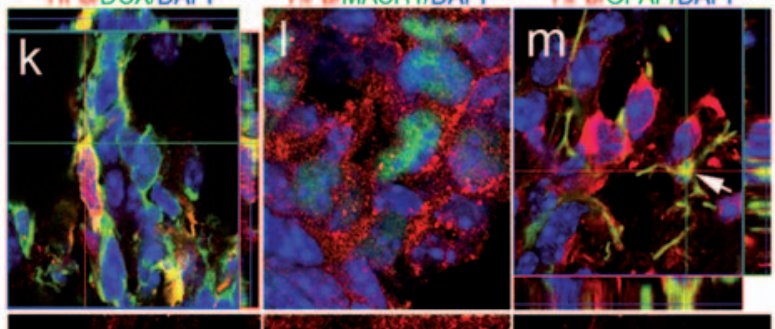

Subventricular Zone
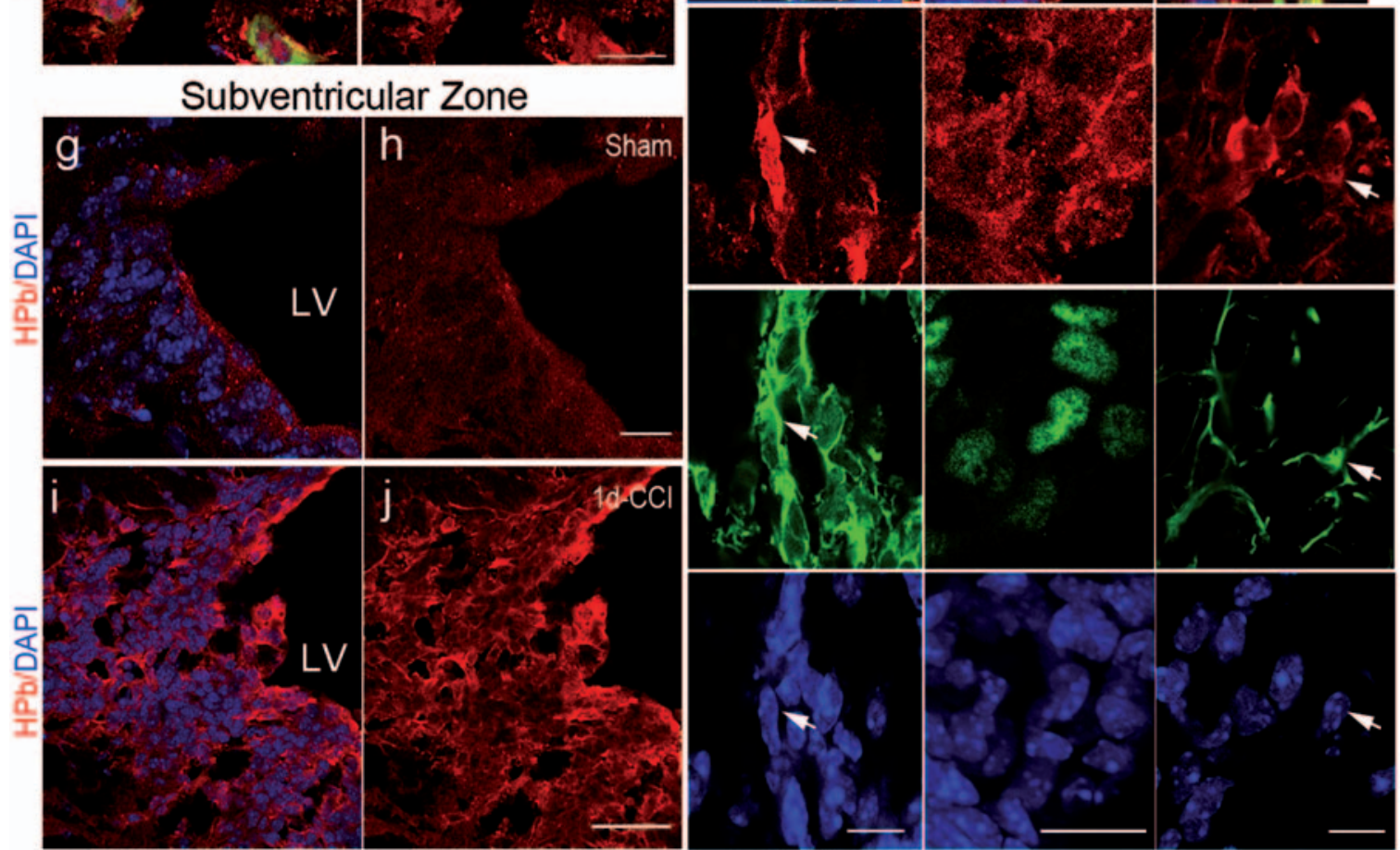

Figure $2 \mathrm{HPb}$ expression in the adult murine forebrain after $\mathrm{CCl}$ injury. (a-d) $\mathrm{HPb}$ (red) expression by immunofluorescence on sagittal sections following sham or CCl injury with $\mathrm{HPb}$ injection. Representative low-magnification images demonstrate that the SVZ and RMS reside within hypoxic regions of the brain after $1.5 \mathrm{~h} \mathrm{CCl}$ injury (b-d) compared to sham-injured (a) controls. HPb is expressed on injured NISSL-positive neurons in the cortex (e and f; scale bar $=20 \mu \mathrm{m}$ ), weakly expressed in the sham-injured SVZ ( $\mathrm{g}$ and h; scale bar $=20 \mu \mathrm{m}$ ) and significantly present at 1 day post-TBI in the SVZ (i and j; scale bar $=50 \mu \mathrm{m}$ ). HPb co-localized with DCX-positive neuroblasts $(\mathrm{k}$; scale bar $=10 \mu \mathrm{m})$, MASH1-positive intermediate progenitors (l; scale bar $=20 \mu \mathrm{m})$ and GFAP-expressing NSPCs (m; scale bar $=10 \mu \mathrm{m})$, in the SVZ neurogenic compartment. (A color version of this figure is available in the online journal) 


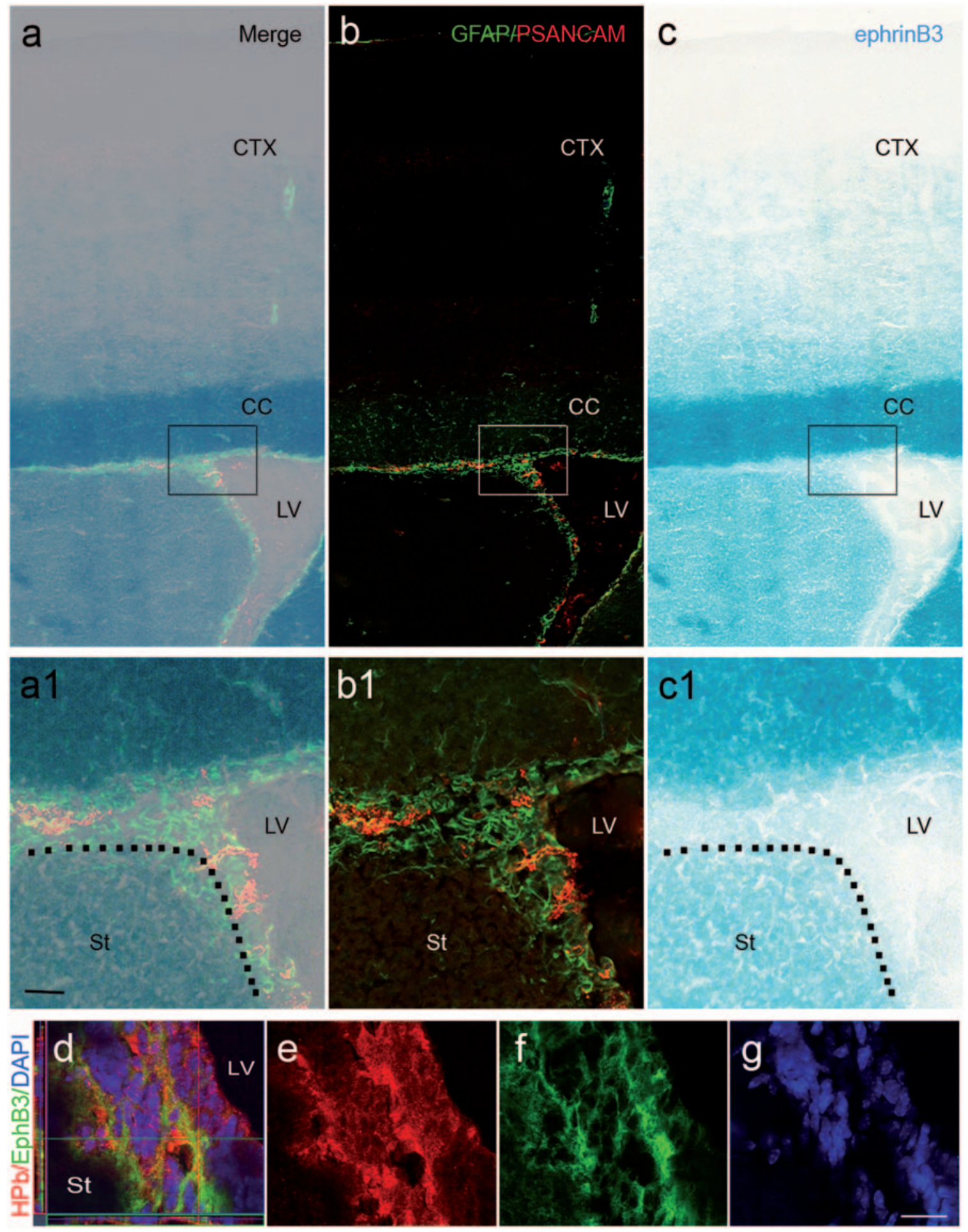

Figure 3 EphB3 and ephrinB3 expression in the adult murine forebrain. (a-c) Immunofluorescence labeling and $\beta$-gal staining on sagittal sections from naïve ephrinB3 $^{\beta g a l}$ mice. (a) Low-magnification overlay image of immunofluorescence labeling of anti-GFAP and anti-PSA-NCAM (b) with $\beta$-gal staining of ephrinB3 (c). EphrinB3 is robustly expressed in the corpus callosum, striatum, and weakly expressed in the ventral cortex. (a1-c1) Conversely, high-magnification images show the absence of ephrinB3 in the SVZ. GFAP-expressing NSPCs (green) and PSA-NAM-positive neuroblasts (red) reside in the lining of the lateral ventricular wall adjacent to the $\beta$-gal staining (insets from a-c; black dotted lines). (d-g) EphB3 expression co-labels with HPb hypoxia marker in the SVZ and is absent in the striatum. CTX: cortex; CC: corpus callosum; LV: lateral ventricle; St: striatum. Scale bar $(a 1-c 1)=100 \mu \mathrm{m} ;(d-g)=20 \mu \mathrm{m}$. (A color version of this figure is available in the online journal) 

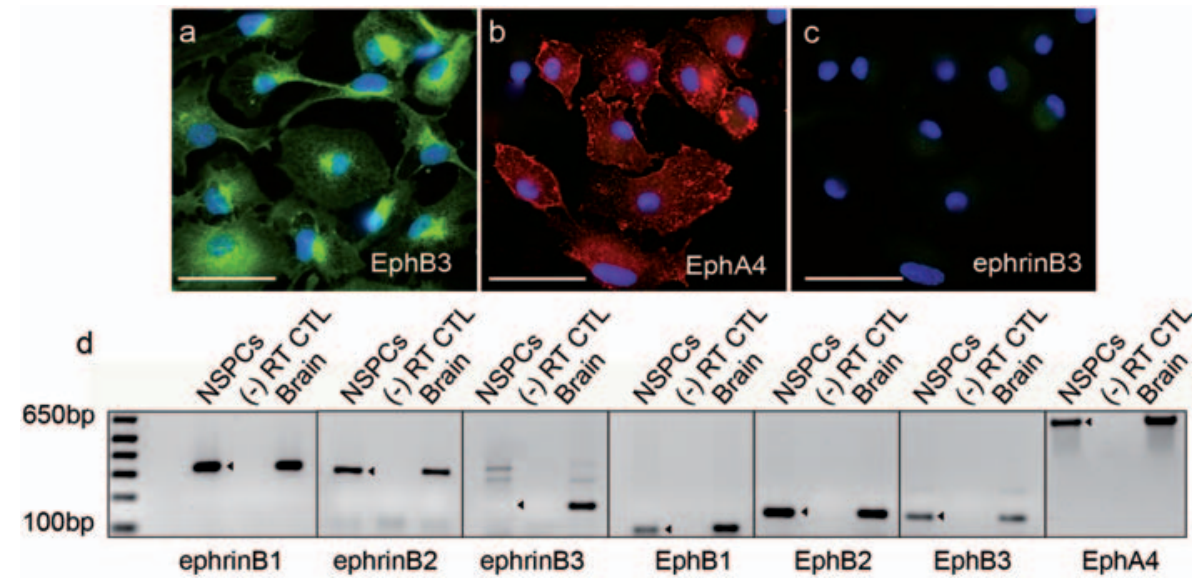

Figure 4 EphB3 and ephrinB3 expression on cultured NSPCs derived from the SVZ. Immunofluorescence labeling shows expression of EphB3 (a) and EphA4 (b) receptors but not ephinB3 ligand (c) on NSPCs. Using reverse transcriptase (RT)-PCR, we confirmed the expression of EphB3, EphA4 and the absence of ephrinB3 transcripts (d). NSPCs also express transcripts for EphB1, EphB2, ephrinB1 and ephrinB2. Lane 1: NSPCs; lane 2: (-)RT control; lane 3: total adult brain RNA extract. Scale bar $(\mathrm{a}-\mathrm{c})=50 \mu \mathrm{m}$. (A color version of this figure is available in the online journal)

\section{EphB3 stimulation limits hypoxia-induced proliferation in cultured NSPCs}

We recently showed that interaction with ephrinB3 limits NSPC proliferation in the SVZ. ${ }^{24,25}$ This effect is blocked in the absence of EphB3 receptor, ${ }^{24}$ demonstrating the specificity of the EphB3/ephrinB3 pathway. To overcome this inhibitory signal, EphB3 expression is downregulated, concomitant with increased NSPC proliferation following $\mathrm{TBI}^{24}$ In order to assess whether hypoxia could be an early initiating factor that modulates EphB3 signaling, we established an in vitro hypoxia assay by culturing SVZderived NSPCs in an airtight oxygen controlled humidified chamber that maintains $1 \%$ oxygen (hypoxia) or under standard culture conditions (normoxia). Using Western Blot analysis, we first observed that EphB3 expression on NSPCs was significantly reduced when exposed to hypoxia $(\mathrm{HP})$ at $24 \mathrm{~h}(0.23 \pm 0.04$ compared to $0.38 \pm 0.05$ normoxia $)$, $48 \mathrm{~h}(0.28 \pm 0.04$ compared to $0.41 \pm 0.03$ normoxia), and $72 \mathrm{~h}(0.27 \pm 0.04$ compared to $0.51 \pm 0.08$ normoxia), (Figure 5a and b). Conversely, phosphorylated AKT (pAKT) levels, which are normally suppressed by EphB3 signaling, ${ }^{24}$ are increased under hypoxia at $24 \mathrm{~h}(0.51 \pm 0.09$ compared to $0.25 \pm 0.05$ normoxia) and $72 \mathrm{~h}(1.03 \pm 0.22$ compared to $0.65 \pm 0.11$ normoxia) (Figure $5 \mathrm{a}$ and c).

We next assessed whether reduced EphB3 expression was concomitant with increased proliferation and whether the presence of soluble aggregated ephrinB3 (eB3), ${ }^{29}$ which mimics the in vivo environment within the neurogenic compartment, would limit this effect. To test this, we treated SVZ-derived NSPCs with either $10 \mu \mathrm{g} / \mathrm{mL}$ eB3 or vehicle control and placed them under hypoxia or normoxia for 24,48 and $72 \mathrm{~h}$ followed by $1 \mathrm{~h}$ incubation in $10 \mu \mathrm{M}$ bromodeoxyuridine (BrdU) (Figure 6). We observed a significant increase in the number of BrdU-positive NSPCs when exposed to hypoxia at $24 \mathrm{~h} \quad(21.34 \pm 0.8 \%$ compared to $16.9 \pm 0.9 \%$ normoxia), $48 \mathrm{~h}(29.5 \pm 0.8 \%$ compared to $24.4 \pm 1.8 \%$ normoxia) and $72 \mathrm{~h}(28.7 \pm 0.6 \%$ compared to $23.5 \pm 0.6 \%$ normoxia) (Figure 6e). The total number of
NSPCs per well was also significantly increased under hypoxia at $48 \mathrm{~h}$ (1312 \pm 83.7 compared to $723.4 \pm 86.9$ normoxia) and $72 \mathrm{~h}(3248 \pm 124.7$ compared to $2158 \pm 87.69$ normoxia (Figure 6f). However, the addition of eB3 significantly attenuated hypoxia-mediated proliferation at $24 \mathrm{~h}(21.34 \pm 0.8 \%$ vehicle compared to $16.3 \pm 1.7 \%$ eB3) and $48 \mathrm{~h}(29.5 \pm 0.8 \%$ vehicle compared $26.6 \pm 0.6 \%$ eB3) (Figure $6 \mathrm{~d}$ and e) which subsequently lead to an overall reduction in the total number of cells per well at $72 \mathrm{~h}(3248 \pm 124.7$ vehicle compared to $2577 \pm 132.5$ eB3) compared to vehicle control (Figure 6f). Finally, while the presence of eB3 attenuated hypoxia-induced proliferation, the numbers were not restored completely back to normoxic levels. Additionally, eB3 failed to attenuate hypoxia-induced proliferation in NSPCs derived from EphB3 ${ }^{-/-}$mice (data not shown). These results indicate that eB3 limits the NSPC response to hypoxic stimuli via EphB3 forward signaling and suggests that the response in vivo could be enhanced on those NSPCs not directly in contact with eB3 ligand.

We also assessed whether eB3 could reduce proliferation by elevating cell death. Although we previously demonstrated reduced cell death in the presence of eB3, ${ }^{24}$ we show that eB3 also reduced cell death under hypoxic conditions (Figure $6 \mathrm{~g})$ at $24 \mathrm{~h}(16.7 \pm 1.2 \%$ vehicle compared to $5.6 \pm 1.4 \%), \quad 48 \mathrm{~h} \quad(11.3 \pm 1.6 \%$ vehicle compared to $3.5 \pm 1.0 \%)$, and $72 \mathrm{~h}(7.8 \pm 1.3 \%$ vehicle compared to $2.1 \pm 0.9 \%)$.

\section{Hif1- $\alpha$ is not regulated by ephrinB3/EphB3 signaling under hypoxia}

Hypoxia inducible factor- 1 alpha (Hif1- $\alpha$ ) elicits the expression of a plethora of growth-promoting genes responsible for stimulating proliferation, survival and differentiation of stem cells under low oxygen conditions. ${ }^{30-33}$ To further elucidate the mechanism(s) by which ephrinB3/EphB3 signaling limits hypoxia-induced proliferation of NSPCs, we assessed whether EphB3 stimulation could prevent early activation of Hif1- $\alpha$. Soluble eB3 was added at the time 

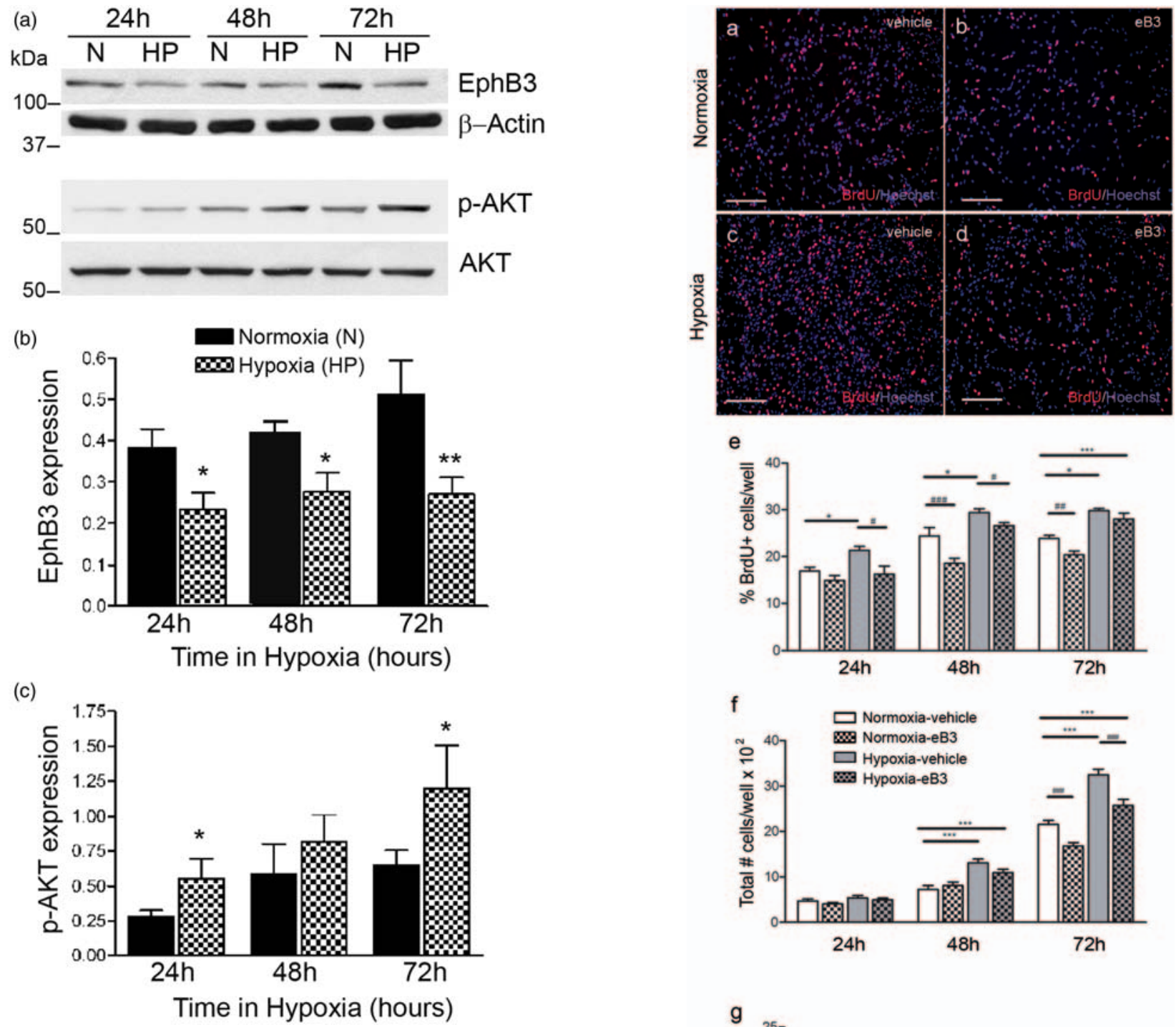

Figure 5 EphB3 expression is reduced under hypoxia cell culture conditions. NSPCs were grown under hypoxic (HP) or normoxic (N) cell culture conditions for 24-72 h. (a) Using Western Blot analysis, we found EphB3 expression was reduced; conversely, p-AKT was increased under hypoxia compared to normoxia. (b) Bar graph representing quantified relative expression of EphB3 at 24$72 \mathrm{~h}$ in hypoxic or normoxic cultures. Grey intensity values were normalized against $\beta$-actin control levels. (c) Bar graph representing quantified data for $\mathrm{p}$-AKT normalized to total AKT levels at $24-72 \mathrm{~h}$ in culture. ${ }^{*} P<0.05$ and ${ }^{* *} P<0.01$ compared to normoxia control NSPC cultures

NSPCs were placed in hypoxia and the effects of EphB3 stimulation on early Hif1- $\alpha$ activation was assessed using Western Blot analysis. We found that Hif1- $\alpha$ expression increased at $12 \mathrm{~h}$ hypoxia exposure $(0.44 \pm 0.05$ compared to $0.13 \pm 0.03$ normoxia) and was unaffected by the addition of either $10 \mu \mathrm{g} / \mathrm{mL}$ soluble aggregated eB3 $(0.48 \pm 0.07)$ or $10 \mu \mathrm{g} / \mathrm{mL}$ eB1 $(0.33 \pm 0.08)$ compared to vehicle control $(0.4370 \pm 0.05)$ (Figure $7 \mathrm{a}$ and $\mathrm{b})$. On the other hand, Hif1$\alpha$ accumulation was prevented following treatment with $50 \mu \mathrm{m}$ AKT inhibitor LY294002 (0.14 \pm 0.01 compared to vehicle $0.44 \pm 0.05$ ), as expected (Figure $7 \mathrm{a}$ and $\mathrm{c}$ ). The AKT/PI3 kinase pathway is a known inducer of Hif1- $\alpha$ under hypoxic conditions ${ }^{34,35}$ and is blocked following

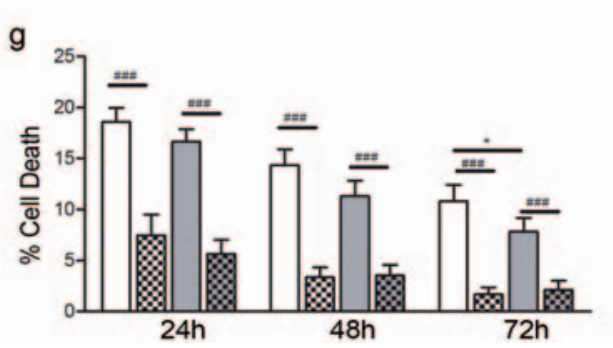

Figure 6 Stimulation with ephrinB3 attenuates hypoxia-induced proliferation on SVZ-derived NSPCs. The proliferation of SVZ-derived NSPCs was assessed using bromodeoxyuridine (BrdU) incorporation in the presence and absence of soluble aggregated ephirnB3 ligand (eB3) at 24-72 h under low oxygen conditions. (a-d) Immunofluorescence labeling of cultured NSPCs under hypoxia showed a significant increase in BrdU incorporation at $72 \mathrm{~h}$ hypoxia exposure (c) compared to normoxia (a). However, cell numbers are reduced when normoxic or hypoxic NSPCs were grown in the presence of eB3 (b and d). (e) Bar graph representing the percentage (\%) of BrdU-positive NSPCs shows that hypoxiainduced proliferation was significantly attenuated following 24 and $48 \mathrm{~h}$ exposure to eB3 compared to vehicle control. (f) Bar graph representing the total number of NSPCs per well $\left(\times 10^{2}\right)$ demonstrates a significant overall reduction in the amount of NSPCs present after $72 \mathrm{~h}$ stimulation with eB3 under hypoxia compared to vehicle control. (g) Bar graph showing reduced cell death in the presence of eB3 and hypoxia. ${ }^{*} P<0.05$ and ${ }^{* \star *} P<0.001$ compared to normoxia-vehicle; $\# P<0.05, \# \#>0.01$ and \#\#\#P<0.001 compared to hypoxia-vehicle. The number of $\mathrm{BrdU}+$ cells were calculated as a percentage of total Hoechst + cells per well. (A color version of this figure is available in the online journal) 
Baumann et al. Pronounced hypoxia in the subventricular zone following traumatic brain injury and the neural stem/progenitor cell response 837

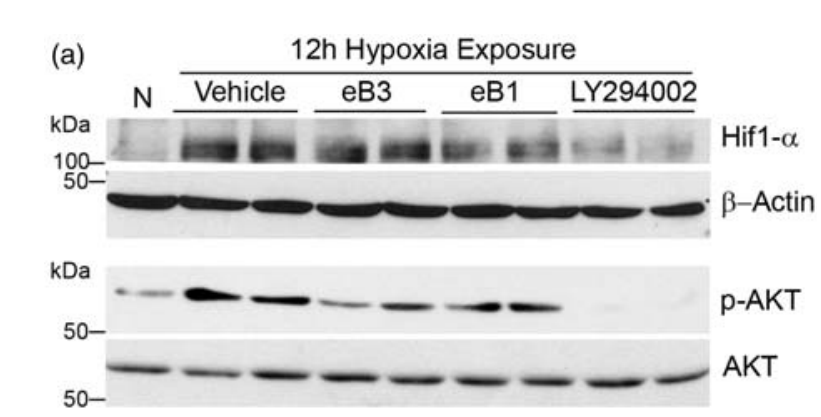

(b)

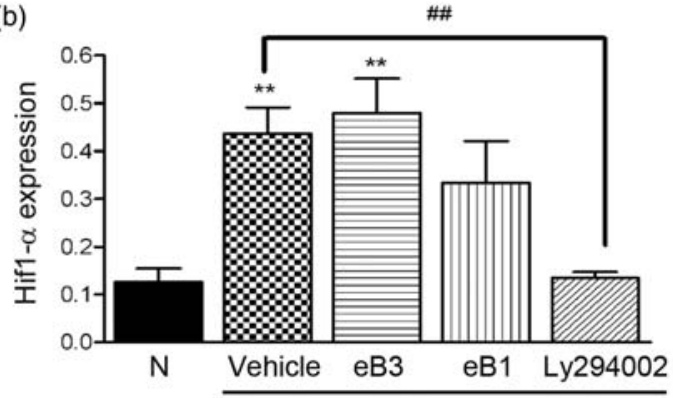

12h Hypoxia Exposure

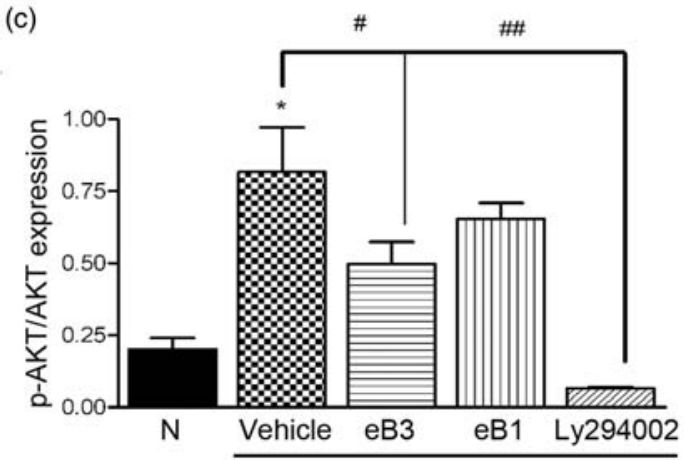

12h Hypoxia Exposure

Figure 7 Hif1- $\alpha$ induction is not regulated by ephrinB3. (a) The expression of Hif1- $\alpha$ and $p$-AKT in cultured NSPCs was assessed using Western Blot analysis following $12 \mathrm{~h}$ hypoxia exposure. Both Hif1- $\alpha$ and phosphorylated (p)-AKT expression are increased with hypoxia compared to normoxia (N). Inhibition with $50 \mu \mathrm{m}$ PI3K/AKT pharmacological inhibitor LY294002, prevented AKT phosphorylation and blocked Hif1- $\alpha$ induction compared to vehicle treatment. Although the application of $10 \mu \mathrm{g} / \mathrm{mL}$ eB3 and $10 \mu \mathrm{g} / \mathrm{mL}$ eB1 also significantly reduced p-AKT levels under hypoxia, the induction of Hif1- $\alpha$ was unaffected. (b) Bar graph representing quantified relative expression of Hif1- $\alpha$ at $12 \mathrm{~h}$ hypoxia or normoxia exposure. Grey intensity values were normalized against $\beta$-actin control levels. (c) Bar graph representing quantified data for p-AKT normalized to total AKT levels. ${ }^{*} P<0.05$ and ${ }^{* *} P<0.01$ compared to normoxia control NSPC cultures. $\# P>0.05$ and $\# \# P<0.01$ compared to hypoxia treated vehicle control

EphB3 activation. ${ }^{36}$ Although we found the p-AKT levels to be significantly attenuated in the presence of eB3 $(0.42 \pm 0.06$ compared to vehicle control $0.76 \pm 0.09)$ under hypoxia vs. normoxia $(0.18 \pm 0.03)$ (Figure $7 \mathrm{a}$ and $\mathrm{c})$, it had no effect on the expression of Hif1- $\alpha$ (Figure 7b) suggesting a threshold of p-AKT inactivation must be reached to affect Hif1- $\alpha$ induction. These data also indicate that EphB3 limits hypoxia-induced proliferation in the presence of ephrinB3 through Hif1- $\alpha$ independent pathway(s).

\section{Discussion}

Adult NSPCs are localized to the SVZ/RMS and the dentate gyrus of the hippocampus. ${ }^{37,38}$ The cells residing in these adult neurogenic compartments are transiently stimulated to proliferate and migrate to areas of injury. $8,12,24$ However, it remains unclear what early initiating factors precede these changes following the initial trauma. Here, using the $\mathrm{HPb}$ biochemical marker of hypoxia, we show $\mathrm{HPb}$ localization in the SVZ on GFAP-positive stem cells, MASH1-positive intermediate progenitor cells and DCXpositive neuroblasts in the first $24 \mathrm{~h}$ after TBI. This indicates that the local milieu within the $\mathrm{SVZ}$ niche has a $\mathrm{pO}_{2}$ less than $10 \mathrm{mmHg}(\leq 1 \%)$. Importantly, it is reasonable to believe that the NSPCs may respond favorably to this new hypoxic environment. Previously, we identified EphB3 as a negative regulator of NSPC activity which is downregulated in the SVZ after TBI. ${ }^{24}$ Our current findings demonstrate the regional change in oxygen tension appears to correlate with reduced levels of EphB3 in the SVZ after TBI. NSPCs express $\mathrm{HPb}$ at $24 \mathrm{~h}$ post-TBI in the lateral wall of the ventricle, an area previously shown to have increased proliferation and enhanced survival. In order to examine the cell autonomous effects of hypoxia on NSPCs, we exposed them to a $1 \%$ oxygen environment in vitro. Similar to our previous in vivo findings, ${ }^{24}$ we observed that the level of EphB3 expression on SVZ-derived NSPCs is significantly reduced in hypoxia compared to normoxia. This change is accompanied by increased Hif1- $\alpha$ expression, BrdU incorporation and reduced cell death. Importantly, p-AKT, known to be suppressed by EphB3 signaling, is significantly upregulated during this time. Therefore, downregulating this pathway on NSPCs in the SVZ following TBI may be preceded by localized transient hypoxia to initiate population expansion in the neurogenic compartment.

Neurogenesis in the SVZ is tightly regulated by ephrins and Eph receptors. Specifically, the proliferation of NSPCs expressing EphB3 receptor, are negatively regulated by the interaction with membrane-bound ephrinB3 ligand (eB3) in the tissue surrounding the SVZ. Although Eph receptors have been shown to be fairly promiscuous, ephrinB3 fails to suppress NSPC growth in the absence of EphB3. These previous findings solidify the role of EphB3/ephrinB3 interaction as a negative regulator in the SVZ. We therefore sought to understand how hypoxic NSPCs would respond in the presence and absence of eB3. We show that even though proliferation was increased in hypoxia, cells stimulated with eB3 grew significantly less than vehicle control. This suggests that hypoxia downregulates EphB3 expression to induce proliferation and that NSPCs in the SVZ may have a greater growth response to lowered oxygen when not directly in contact with eB3. While the early activation of hypoxia-inducible factor-1 alpha (Hif1- $\alpha$ ) is unaltered by eB3 stimulation, growth suppression may be regulated downstream of Hif1- $\alpha$ by other signaling pathways known to be suppressed by Eph signaling such as PI3/AKT and ERK/MAPK. ${ }^{19}$

Lowered oxygen conditions have been shown to mimic the embryonic setting, promote proliferation, survival and 
in some cases directed differentiation of neural crest stem cells and embryonic neural precursor cells. ${ }^{30-32}$ Several studies indicate that redox metabolism in stem cells is differentially and uniquely regulated to protect them from oxidative damage. ${ }^{39}$ The ability of stem cells to properly control redox balance is an important property of adult progenitor cells and could help explain why transient hypoxia may create a favorable environment in the neural stem niche following brain injury. ${ }^{33,40-42}$ Physiological hypoxia, on the other hand, exists not only during embryonic development but also in the adult mammalian brain where oxygen levels of interstitial tissue can range from one to $5 \% .{ }^{31}$ Although the importance of tissue hypoxia has been studied in the context of brain development, the effects of hypoxia on the adult neural stem cell niche is just now being investigated. There is sufficient evidence from a variety of experimental systems that describe the role of hypoxia in the proliferation, survival and differentiation of nonneural stem cell populations including embryonic stem (ES) cells, hematopoietic stem cells (HSCs) and trophoblast stem cells. ${ }^{39,43-46}$ We found that NSPCs in the SVZ may also be regulated by changing oxygen conditions, especially in the injured environment. Although our studies addressed the co-labeling of $\mathrm{HPb}$ with Type A, B and C progenitor cells, it is also possible that others such as Olig2 and NG2-expressing cells may express $\mathrm{HPb}$ in the SVZ. Importantly, the direct role of Hif1- $\alpha$ in mediating cellular changes following hypoxia exposure on specific subpopulations of cells in the SVZ will be further investigated using additional models of brain injury.

Hif1- $\alpha$ is a crucial mediator of cellular adaptation to hypoxic stress and is the key element responsible for the regulation, under low oxygen tension, of many genes involved in important biological processes such as glycolysis, proliferation or angiogenesis. ${ }^{6}$ This apparently universal response to hypoxia is consistent with the idea that oxygen levels may be an important component of the stem cell "niche" and that HIF activity can regulate the defining features of stem cells, including self-renewal and multipotency. Elucidation of the relevant molecular mechanisms governing proliferation, survival and differentiation of NSPCs exposed to hypoxia may further our understanding of the neural stem cell niche in the adult brain. We show that hypoxia induced Hif1- $\alpha$ expression in cultured NSPCs and that this effect is blocked in the presence of the AKT inhibitor LY294002. Although stimulation of EphB3 limited hypoxia-mediated p-AKT expression, early activation of Hif1- $\alpha$ was unchanged in the presence of eB3 suggesting that a threshold of $\mathrm{p}$-AKT suppression may be necessary for blocking Hif1- $\alpha$ induction. Although it is possible that EphB3/ephrinB3 signaling may affect Hif1- $\alpha$ expression at later time points, this is unlikely as we would expect differences in HIf1- $\alpha$ to precede the proliferative changes observed at $24 \mathrm{~h}$.

Recent findings indicate a low oxygen environment exists in the SVZ, as measured by intense $\mathrm{HPb}$ staining, under naïve conditions. ${ }^{47}$ Conversely, our data indicates minimal $\mathrm{HPb}$ staining in the sham-injured SVZ which is greatly enhanced $24 \mathrm{~h}$ post-TBI. This difference may be due to the time at which the tissue was harvested following
$\mathrm{HPb}$ injection. The previous study reported extracting the tissue $30 \mathrm{~min}$ after $\mathrm{HPb}$ injection; however, the half-life for $\mathrm{HPb}$ is $90 \mathrm{~min}$. If residual systemic $\mathrm{HPb}$ still remains, false positive staining could occur in areas experiencing hypoxia during tissue extraction. This is not an indication of true hypoxia, as demonstrated in our studies where the time between $\mathrm{HPb}$ injection and tissue retrieval was $4 \mathrm{~h}$. Using this biochemical marker, we were able to demonstrate that NSPCs in the SVZ experience early changes in oxygen tension as a result of cortical trauma. Given the beneficial role of transient hypoxia on stem cell activities, we believe this finding represents a novel mechanism regulating early events in the neurogenic compartment following TBI. We also show that EphB3/ephrinB3 negatively regulates the proliferation of NSPCs under homeostatic and hypoxic conditions and that downregulating this pathway is critical for NSPC expansion. Although our initial studies do not implicate EphB3 forward signaling in regulating Hif1- $\alpha$, future studies will focus on confirming these results in vivo as well as identifying potential downstream pathways that may be interrupted within the hypoxic milieu as a result of EphB3 activation.

\section{Materials and methods Animals and $\mathrm{CCl}$ injury}

The maintenance of CD1 and ephrinB3 ${ }^{\beta g a l}$ mice and genotyping using PCR analysis has been previously described. ${ }^{25,48-51}$ Procedures related to animal use and care was approved by Virginia Tech and the University of Miami Animal Use and Care Committee. Male mice ages 2-4 months were anesthetized with ketamine and xylazine by i.p. injection and positioned in a stereotaxic frame. Body temperature was monitored with a rectal probe and maintained at $37^{\circ} \mathrm{C}$ with a controlled heating pad set. A $5 \mathrm{~mm}$ craniotomy was made using a portable drill over the right parietal-temporal CTX $(-2.5 \mathrm{~mm} \mathrm{~A} / \mathrm{P}$ and $2.0 \mathrm{~mm}$ lateral from bregma). Injury was induced by moderate CCI using the $e$ CCI-6.3 device (Custom Design \& Fabrication) at a velocity of $6 \mathrm{~m} / \mathrm{s}$, depth of $0.5 \mathrm{~mm}$, and $150 \mathrm{~ms}$ impact duration. Sham controls received craniotomy only. Mice were injected once with $100 \mathrm{mg} / \mathrm{kg} \mathrm{HPb}$ dissolved in $1 \times \mathrm{PBS}$ (phosphate buffered saline; Hypoxyprobe Inc., Burlington, MA) at the time of injury $(0 \mathrm{~h})$, or at $1.5 \mathrm{~h}$ and $24 \mathrm{~h}$ postinjury. Mice receiving $\mathrm{HPb}$ at $0 \mathrm{~h}$ and $1.5 \mathrm{~h}$ were sacrificed $24 \mathrm{~h}$ later, and mice that received $\mathrm{HPb}$ at $24 \mathrm{~h}$ were sacrifice $4 \mathrm{~h}$ after injection (i.e. $28 \mathrm{~h}$ after injury). Under anesthesia, mice were sacrificed by transcardial perfusion, with $4 \%$ paraformaldehyde (PFA) in PBS. Brains were removed and post-fixed with $4 \%$ PFA for $4 \mathrm{~h}$ and transferred to $20 \%$ sucrose overnight, then embedded in OCT on dry ice.

\section{Histology}

For immunostaining, perfused-fixed tissue sections were blocked in 5\% BSA for $1 \mathrm{~h}$ and incubated in primary antibodies overnight at $4^{\circ} \mathrm{C}$ (rabbit anti-HPb: 1/100; Hypoxyprobe Inc.; goat anti-DCX: 1/100, Santa Cruz; rabbit anti-GFAP: 1/1000, Dako; mouse antiPSA-NCAM:1/1000, Chemicon; anti-BrdU: 1/100, Roche; 
anti-MASH1 1/100, BD Bioscience) as previously described. ${ }^{24,25}$ Sections were washed 3 times with 1X PBS and incubated with Alexa Fluor 488 - or Alexa Fluor 594conjugated secondary antibodies (Molecular Probes, Carlsbad, CA) $1 \mathrm{~h}$ at RT. Sections were counterstained with Hoechst $(5 \mu \mathrm{g} / \mathrm{mL}$, Molecular probes, Carlsbad, CA) and mounted in Pro-Long anti-fade mounting solution (Molecular probes, Carlsbad, CA). For DAB staining, sections were exposed to vectastain $\mathrm{ABC}$ kit and ImmPACT DAM substrate (Vector lab, Burlingame, CA) according to manufacturer's instructions. $\beta$-gal staining was performed on fresh frozen sections as previously described. ${ }^{25}$

\section{Tissue culture and hypoxia conditions}

Animals were sacrificed by decapitation under anesthesia. Neural stem cells were isolated from the SVZ of adult wild type CD1 mice (2-4 months old) and grown as described by Scheffler et al..$^{52}$ The ventricle wall on the striatal side was dissected out and the tissue was dissociated in $1.33 \mathrm{mg} / \mathrm{mL}$ trypsin, $0.7 \mathrm{mg} / \mathrm{mL}$ hyaluronic acid and $0.2 \mathrm{mg} / \mathrm{mL}$ kynurenic acid in HBSS, and placed overnight in $100 \mathrm{~mm}$ bacterial petri dishes in N2 medium (DMEM/F-12, 100 units/mL penicillin, $100 \mu \mathrm{g} / \mathrm{mL}$ streptomycin, N2 supplement, $35 \mu \mathrm{g} / \mathrm{mL}$ bovine pituitary extract, $5 \%$ FBS (Gibco), and $20 \mathrm{ng} / \mathrm{mL}$ epidermal growth factor (EGF) and $10 \mathrm{ng} / \mathrm{mL}$ (bFGF)). Following overnight incubation, unattached cells were collected, gently triturated and replated onto a fresh $100 \mathrm{~mm}$ bacterial petri dish and grown to confluency in N5 medium. Fresh EGF and FGF (20 ng each) were added every other day. Confluent cells were passed once with $0.05 \%$ trypsin (Gibco) and plated at 500,000 cells per $100 \mathrm{~mm}$ petri dish in N2 medium until grown to $80-90 \%$ confluency. For hypoxia exposure: Cells were plated at 2000 cells into each well of a 96-well plate containing $100 \mu \mathrm{L}$ monolayer media. Following overnight incubation at $37^{\circ} \mathrm{C}, 5 \%$ $\mathrm{CO}_{2}$, plates either remained there or were placed in an airtight oxygen controlled ProOx-C-chamber (BioSpherix Ltd, Redfield NY) housed in a $37^{\circ} \mathrm{C}$ incubator to maintain constant and appropriate temperature and humidity. The hypoxia chamber was maintained at $1 \% \mathrm{O}_{2}, 5 \% \mathrm{CO}_{2}$ by infusing a balanced Nitrogen gas mixture in order to reach and maintain the oxygen level at $1 \%$, which was measured and controlled by a ProOx-C oxygen sensor (Model No. 110, BioSpherix Ltd, Redfield NY). Normoxia control was provided according to each time point. For experiments in which the effect of ephrinB3 (eB3) ligand was examined, ephrinB3 protein aggregates ${ }^{29}$ or vehicle control were added to the media just prior to placing the plates in the hypoxia chamber at a concentration of $10 \mu \mathrm{g} / \mathrm{mL}$ per well and incubated up to $72 \mathrm{~h}$. Equal amounts of buffer (vehicle) were added as the control.

\section{Proliferation assessment}

After 24,48 and $72 \mathrm{~h}$ incubation, plates were removed and immediately assessed for proliferation by adding $10 \mu \mathrm{M}$ BrdU. Following $1 \mathrm{~h}$ incubation with BrdU, cells were fixed with $10 \%$ buffered formalin and incubated in $2 \mathrm{~N}$ $\mathrm{HCl}$ as previously described. ${ }^{24}$ Cells were counterstained
Hoechst and analyzed under TRITC/DAPI filters on a Zeiss Axiophot microscope equipped with a CCD camera. Six images per well were acquired by using Cellomics kinetic scan HCS reader (Thermo Fisher) and quantified as percentage of BrdU by VHCS scan software (Thermo Fisher) (TRITC average intensity greater than 100) as previously described. ${ }^{29}$

\section{RT-PCR}

Total RNA of monolayers was isolated by applying Trizol reagent (Invitrogen) and following the manufacturer's protocol. RNA quantification was carried out by measuring absorbance with spectrophotometer ND-1000 (NanoDrop). RNA was reverse transcribed into cDNA with Im-Prom II Reverse Transcription System (Promega). The primers for the genes of interest were as follows: ephrinB1, forward: $5^{\prime}-$ caccatcaagttccaagat-3', reverse: 5'-cttctctcctggttcacag-3'; ephrinB2, forward: $5^{\prime}$-tggaagtactgttggggact, reverse: $3^{\prime}$-tcacatcttggtctggtctg; ephrinB3, forward: 5'-gggaccggctagatctactt-3', reverse: 5'-ggctgtattcctggaacttg-3'; EphB1, forward: $5^{\prime}$-atccggaacccagctagtctcaag- $3^{\prime}$, reverse: $5^{\prime}$-ggtggtaaaggccgtgaagtctg-3'; EphB2, forward: 5'-atccggaacccagctagtctcaag3', reverse: 5'-ggtgtgtaatgtgcgtgagt-3'; EphB3, forward: 5'ggtgtgtaatgtgcgtgagt- $3^{\prime}$, reverse: $5^{\prime}$-tggtgtccactttcacgtag- $3^{\prime}$; EphA4, forward: 5'-aggaagtgagcattatggatga-3', reverse: 5'tgctcctcgtgcccagcgtt- $3^{\prime}$. The PCR products were loaded on $1 \%$ agarose gel and were visualized with ethidium bromide. The reverse transcriptase was omitted in the negative control reaction and cDNA generated from adult mouse brain RNA were used in the positive control reaction. Both controls were applied for each PCR reaction.

\section{Western Blot analysis}

Protein of monolayer cultures was extracted by lysing cells in RIPA buffer (1\% NP-40, 1\% sodium-deoxycholate, $0.1 \%$ SDS, $0.15 \mathrm{M} \mathrm{NaCl}, 2 \mathrm{mM}$ EDTA, and $0.01 \mathrm{M}$ sodium phosphate) in the presence of complete protease inhibitor cocktail (Roche) and phosphatase inhibitor cocktail 2 (Sigma). Supernatant was collected by centrifuging at $13,000 \mathrm{~g}$ for $30 \mathrm{~min}$ at $4^{\circ} \mathrm{C}$ and the Lowry assay was used for the determination of protein concentration (Pierce, Rockford, IL). Cell lysates $(50 \mu \mathrm{g})$ were resolved on $8 \%$ SDS-PAGE gels and blotted onto PVDF membranes, blocked with 5\% milk in TBST buffer ( $20 \mathrm{mM}$ Tris, $137 \mathrm{mM} \mathrm{NaCl}$ and $0.1 \%$ Tween) then incubated in block overnight at $4{ }^{\circ} \mathrm{C}$ with primary antibody against Hif- $1 \alpha$ (mouse, 1:2000 Novus), EphB3 (mouse, 1:1000 ABCAM), phospho-AKT and AKT (rabbit 1:4000 Cell Signaling), or $\beta$-actin (mouse, 1:5000 Sigma). HRP-conjugated secondary antibodies (Jackson Laboratory) were applied to the membrane and developed as previously described..$^{24}$ Blots were quantified by densitometry using acquisition into Adobe Photo Shop (Apple, Cupertino, CA, USA) and analyzing by the NIH Image software (National Institutes of Health, Bethesda, MD, USA). The level of protein expression was normalized according to $\beta$-actin controls or total AKT levels. Samples were run in triplicate. 


\section{Statistical analysis}

Data were graphed using GraphPad Prism, version 4 (GraphPad Software, Inc., San Diego, CA). Student's twotailed $t$ test was used for comparison of two experimental groups. Multiple comparisons were done using one-way and two-way ANOVA where appropriate followed by Tukey test for multiple pairwise examinations. Changes were identified as significant if $P$ was less than 0.05 . Mean values were reported together with the standard error of mean (SEM).

Author contributions: GB and LT carried out the tissue culture and Western Blot analysis. DJL participated in the design of the study and reviewing the manuscript. MHT carried out all in vivo studies, participated in the design of the study, performed the statistical analysis and drafted the manuscript. All authors read and approved the final manuscript.

\section{ACKNOWLEDGEMENTS}

This work was supported by NIH/NINDS NS049545 (DJL), NS30291 (DJL), NS007459 (MHT), NS064699 (MHT), Virginia Tech's Open Access Subvention Fund and the Miami Project to Cure Paralysis.

\section{REFERENCES}

1. Alvarez-Buylla A, Seri B, Doetsch F. Identification of neural stem cells in the adult vertebrate brain. Brain Res Bull 2002;57:751-8

2. Gritti A, Bonfanti L, Doetsch F, Caille I, Alvarez-Buylla A, Lim DA, Galli R, Verdugo JMG, Herrera DG, Vescovi AL. Multipotent neural stem cells reside into the rostral extension and olfactory bulb of adult rodents. J Neurosci 2002;22:437-45

3. Doetsch F, Caille I, Lim DA, Garcia-Verdugo JM, Alvarez-Buylla A. Subventricular zone astrocytes are neural stem cells in the adult mammalian brain. Cell 1999;97:703-16

4. Doetsch F, GarciaVerdugo JM, AlvarezBuylla A. Cellular composition and three-dimensional organization of the subventricular germinal zone in the adult mammalian brain. J Neurosci 1997;17:5046-61

5. Doetsch F, AlvarezBuylla A. Network of tangential pathways for neuronal migration in adult mammalian brain. Proc Natl Acad Sci USA 1996;93:14895-900

6. Doetsch F, Garcia-Verdugo JM, Alvarez-Buylla A. Regeneration of a germinal layer in the adult mammalian brain. Proc Natl Acad Sci USA 1999;96:11619-24

7. Theus MH, Ricard J, Bethea JR, Liebl DJ. EphB3 limits the expansion of neural progenitor cells in the subventricular zone by regulating p53 during homeostasis and following traumatic brain injury. Stem Cells 2010;28:1231-42

8. Chirumamilla S, Sun D, Bullock MR, Colello RJ. Traumatic brain injury induced cell proliferation in the adult mammalian central nervous system. J Neurotrauma 2002;19:693-703

9. Urrea C, Castellanos DA, Sagen J, Tsoulfas P, Bramlett HM, Dietrich WD. Widespread cellular proliferation and focal neurogenesis after traumatic brain injury in the rat. Restor Neurol Neurosci 2007;25:65-76

10. Rice AC, Khaldi A, Harvey HB, Salman NJ, White F, Fillmore H, Bullock MR. Proliferation and neuronal differentiation of mitotically active cells following traumatic brain injury. Exp Neurol 2003;183:406-17

11. Ramaswamy S, Goings GE, Soderstrom KE, Szele FG, Kozlowski DA. Cellular proliferation and migration following a controlled cortical impact in the mouse. Brain Res 2005;1053:38-53

12. Lu D, Mahmood A, Zhang R, Copp M. Upregulation of neurogenesis and reduction in functional deficits following administration of
DEtA/NONOate, a nitric oxide donor, after traumatic brain injury in rats. J Neurosurg 2003;99:351-61

13. Doetsch F, Verdugo JM, Caille I, Alvarez-Buylla A, Chao MV, CasacciaBonnefil P. Lack of the cell-cycle inhibitor p27Kip1 results in selective increase of transit-amplifying cells for adult neurogenesis. J Neurosci 2002;22:2255-64

14. Jin K, Sun Y, Xie L, Batteur S, Mao XO, Smelick C, Logvinova A, Greenberg DA. Neurogenesis and aging: FGF-2 and HB-EGF restore neurogenesis in hippocampus and subventricular zone of aged mice. Aging Cell 2003;2:175-83

15. Leone DP, Relvas JB, Campos LS, Hemmi S, Brakebusch C, Fassler R, Ffrench-Constant C, Suter U. Regulation of neural progenitor proliferation and survival by beta1 integrins. J Cell Sci 2005;118:2589-99

16. Ohnuma S, Harris WA. Neurogenesis and the cell cycle. Neuron 2003;40:199-208

17. Wang TW, Zhang H, Parent JM. Retinoic acid regulates postnatal neurogenesis in the murine subventricular zone-olfactory bulb pathway. Development 2005;132:2721-32

18. Flanagan JG, Vanderhaeghen P. The ephrins and Eph receptors in neural development. Annu Rev Neurosci 1998;21:309-45

19. Blits-Huizinga CT, Nelersa CM, Malhotra A, Liebl DJ. Ephrins and their receptors: binding versus biology. IUBMB Life 2004;56:257-65

20. Skold MK, von Gertten C, Sandberg-Nordqvist AC, Mathiesen T, Holmin S. VEGF and VEGF receptor expression after experimental brain contusion in rat. J Neurotrauma 2005;22:353-67

21. Mignone JL, Kukekov V, Chiang AS, Steindler D, Enikolopov G. Neural stem and progenitor cells in nestin-GFP transgenic mice. J Comp Neurol 2004;469:311-24

22. Bessis A, Bechade C, Bernard D, Roumier A. Microglial control of neuronal death and synaptic properties. Glia 2007;55:233-8

23. Myer DJ, Gurkoff GG, Lee SM, Hovda DA, Sofroniew MV. Essential protective roles of reactive astrocytes in traumatic brain injury. Brain: J Neurol 2006;129:2761-72

24. Theus MH, Ricard J, Bethea JR, Liebl DJ. EphB3 limits the expansion of neural progenitor cells in the subventricular zone by regulating p53 during homeostasis and following traumatic brain injury. Stem Cells 2010;28:1231-42

25. Ricard J, Salinas J, Garcia L, Liebl DJ. EphrinB3 regulates cell proliferation and survival in adult neurogenesis. $\mathrm{MOl}$ Cell Neurosci 2006;31:713-22

26. Katakowski M, Zhang Z, deCarvalho AC, Chopp M. EphB2 induces proliferation and promotes a neuronal fate in adult subventricular neural precursor cells. Neurosci Lett 2005;385:204-9

27. Xing S, He Y, Ling L, Hou Q, Yu J, Zeng J, Pei Z. Blockade of EphB2 enhances neurogenesis in the subventricular zone and improves neurological function after cerebral cortical infarction in hypertensive rats. Brain Res 2008;1230:237-46

28. Conover JC, Doetsch F, Garcia-Verdugo JM, Gale NW, Yancopoulos GD, Alvarez-Buylla A. Disruption of Eph/ephrin signaling affects migration and proliferation in the adult subventricular zone. Nat Neurosci 2000;3:1091-7

29. Nelersa CM, Barreras H, Runko E, Ricard J, Shi Y, Glass SJ, Bixby JL, Lemmon VP, Liebl DJ. High-content analysis of proapoptotic EphA4 dependence receptor functions using small-molecule libraries. J Biomol Screen 2012;17:785-95

30. Morrison SJ, Csete M, Groves AK, Melega W, Wold B, Anderson DJ. Culture in reduced levels of oxygen promotes clonogenic sympathoadrenal differentiation by isolated neural crest stem cells. J Neurosci 2000;20:7370-6

31. Studer L, Csete M, Lee SH, Kabbani N, Walikonis J, Wold B, McKay R. Enhanced proliferation, survival, and dopaminergic differentiation of CNS precursors in lowered oxygen. J Neurosci 2000;20:7377-83

32. Milosevic J, Schwarz SC, Krohn K, Poppe M, Storch A, Schwarz J. Low atmospheric oxygen avoids maturation, senescence and cell death of murine mesencephalic neural precursors. J Neurochem 2005;92:718-29

33. Keith B, Simon MC. Hypoxia-inducible factors, stem cells, and cancer. Cell 2007;129:465-72

34. Mottet D, Dumont V, Deccache Y, Demazy C, Ninane N, Raes M, Michiels C. Regulation of hypoxia-inducible factor-1alpha protein level 
during hypoxic conditions by the phosphatidylinositol 3-kinase/Akt/ glycogen synthase kinase 3 beta pathway in HepG2 cells. J Biol Chem 2003;278:31277-85

35. Pore N, Jiang Z, Shu HK, Bernhard E, Kao GD, Maity A. Akt1 activation can augment hypoxia-inducible factor-1alpha expression by increasing protein translation through a mammalian target of rapamycin-independent pathway. Mol Cancer Res: MCR 2006;4:471-9

36. Pasquale EB. Eph-ephrin bidirectional signaling in physiology and disease. Cell 2008;133:38-52

37. Altman J, Das GD. Autoradiographic and histological evidence of postnatal hippocampal neurogenesis in rats. J Comp Neurol 1965;124:319-35

38. Reynolds BA, Weiss S. Generation of neurons and astrocytes from isolated cells of the adult mammalian central nervous system. Science 1992;255:1707-10

39. Ogasawara MA, Zhang $H$. Redox regulation and its emerging roles in stem cells and stem-like cancer cells. Antioxid Redox Signal 2009;11:1107-22

40. Ostrakhovitch EA, Semenikhin OA. The role of redox environment in neurogenic development. Arch Biochem Biophys 2013;534:44-54

41. Vieira HL, Alves PM, Vercelli A. Modulation of neuronal stem cell differentiation by hypoxia and reactive oxygen species. Prog Neurobiol 2011;93:444-55

42. Panchision DM. The role of oxygen in regulating neural stem cells in development and disease. J Cell Physiol 2009;220:562-8

43. Theus MH, Wei L, Cui L, Francis K, Hu X, Keogh C, Yu SP. In vitro hypoxic preconditioning of embryonic stem cells as a strategy of promoting cell survival and functional benefits after transplantation into the ischemic rat brain. Exp Neurol 2008;210:656-70

44. Roy S, Tripathy M, Mathur N, Jain A, Mukhopadhyay A. Hypoxia improves expansion potential of human cord blood-derived hematopoietic stem cells and marrow repopulation efficiency. Eur J Haematol 2012;88:396-405

45. Chen B, Longtine MS, Nelson DM. Hypoxia induces autophagy in primary human trophoblasts. Endocrinology 2012;153:4946-54

46. Chakraborty D, Rumi MA, Soares MJ. NK cells, hypoxia and trophoblast cell differentiation. Cell Cycle 2012;11:2427-30

47. Culver JC, Vadakkan TJ, Dickinson ME. A specialized microvascular domain in the mouse neural stem cell niche. PLoS ONE 2013;8:e53546

48. Henkemeyer M, Orioli D, Henderson JT, Saxton TM, Roder J, Pawson T, Klein R. Nuk controls pathfinding of commissural axons in the mammalian central nervous system. Cell 1996;86:35-46

49. Orioli D, Henkemeyer M, Lemke G, Klein R, Pawson T. Sek4 and Nuk receptors cooperate in guidance of commissural axons and in palate formation. EMBO J 1996;15:6035-49

50. Yokoyama N, Romero MI, Cowan CA, Galvan P, Helmbacher F, Charnay P, Parada LF, Henkemeyer M. Forward signaling mediated by ephrin-B3 prevents contralateral corticospinal axons from recrossing the spinal cord midline. Neuron 2001;29:85-97

51. Cowan C, Yokoyama N, Bianchi L, Henkemeyer M, Fritzsch B. EphB2 guides axons at the midline and is necessary for normal vestibular function. Neuron 2000;26:417-30

52. Scheffler B, Walton NM, Lin DD, Goetz AK, Enikolopov G, Roper SN, Steindler DA. Phenotypic and functional characterization of adult brain neuropoiesis. Proc Natl Acad Sci USA 2005;102:9353-8

(Received October 1, 2013, Accepted April 11, 2013) 